\title{
Blood-brain barrier damage as a predictor of outcome in patients with purulent meningitis
}

Shemsedin Dreshaj ${ }^{1}$, Nexhmedin Shala ${ }^{2}$, Albina Ponosheci ${ }^{1}$, Ajete Aliu-Bejta ${ }^{1}$, Lindita Ajazaj-Berisha ${ }^{1}$

\author{
${ }^{1}$ University of Prishtina, Faculty of Medicine, Clinic of Infectious Diseases, Prishtina \\ University Clinical Centre, Kosovo \\ ${ }^{2}$ University of Prishtina, Faculty of Medicine, Clinic of Neurology, Prishtina University \\ Clinical Centre, Kosovo
}

Submitted: 11 February 2018

Accepted: 6 April 2018

Arch Med Sci Civil Dis 2018; 3: e26-e33

DOI: https://doi.org/10.5114/amscd.2018.75532

Copyright @ 2018 Termedia \& Banach

\section{Abstract}

Introduction: Purulent meningitis is a severe infection of the central nervous system caused by different bacteria and very often causes severe complications and high lethality. Since the disease still has unclear pathogenesis and high mortality, researchers and clinicians are focused on the influence of damage of the blood-brain barrier (BBB) and its subsequent impact on the outcome of purulent meningitis. The aim of this study was to investigate the albumin concentration and the albumin coefficient as the best parameters of BBB damage, and their influence on the outcome of patients with purulent meningitis.

Material and methods: The study was carried out by examining the hospitalized patients in the Clinic of Infective Diseases in Prishtina, Kosovo. Blood-brain barrier damage is evaluated by analyzing the dynamics of values of proteins, glucose and albumins, as well as by determining the BBB coefficient of damage.

Results: The data consistent with BBB damage in patients with purulent meningitis corresponded with disease outcome. Consequently, $56.97 \%$ of the patients who developed complications or died had very severe BBB damage. Patients with the mean value of albumin coefficient $\bar{X}=46.5 \pm 27.23$ $\mathrm{g} / \mathrm{l}$ were at higher risk of developing complications (relative risk $(\mathrm{RR})=2.63$; $p<0.0001)$ or having a lethal outcome $(R R=5.20 ; p<0.0001)$. Patients with longer duration of pathological mean values of albumin coefficient were at higher risk of developing complications $(R R=3.11 ; p<0.0001)$.

Conclusions: Our data suggest that BBB damage in patients with purulent meningitis correspond with disease outcome. The best predictors for outcome were albumin coefficient and albumin concentration in cerebrospinal fluid.

Keywords: purulent meningitis, cerebrospinal fluid, blood-brain barrier, albumin coefficient, Kosovo.

\section{Introduction}

Considering the fact that purulent meningitis is still a very serious disease, often associated with severe neurological complications and a high mortality rate, it still raises dilemmas concerning the aspects of treatment and expected outcome [1, 2].

Experimental animal models showed that the use of antibiotics in treatment of bacterial meningitis worsened meningeal inflammation

\author{
Corresponding author: \\ Nexhmedin Shala \\ Faculty of Medicine \\ Clinic of Neurology \\ Prishtina University \\ Clinical Centre \\ Xhorxh Bush n.n. 10000 \\ Prishtina, Kosovo \\ E-mail: drnexhmedin_shala@ \\ hotmail.com
}


and consequently the outcome of the disease [3]. This was attributed to the release of local inflammatory mediators, causing damage of the central nervous system (CNS) and blood-brain barrier (BBB) [4-6]. In an animal model of pneumococcal meningitis, Lutsar et al. found that the use of dexamethasone has beneficial effects at the early stage of the disease, whereas these effects on the later course are minor [7]. Human studies showed that severe BBB damage, in patients suffering from acute bacterial and viral CNS infections, resulted in prolonged hospitalizations and potentially neurological complications [8-10].

Data from recent studies (focused on bloodbrain barrier permeability) and attempts to modify inflammatory changes by using dexamethasone as an anti-inflammatory drug are inconsistent [1117]. Performing a study by using dexamethasone in patients with CNS infections, Giasuddin et al. documented non-significant improvement of BBB damage [18], while other clinical studies demonstrated that the use of dexamethasone reduces cerebrospinal fluid (CSF) inflammation, early deaths and neurological complications [1, 2, 14]. On the other hand, in a study with 301 adult patients with bacterial meningitis, de Gans and van De Beek found that dexamethasone reduces the risk of death and poor outcome [17]. In this context, some authors recommend the use of dexamethasone before the start of antibiotic treatment, to reduce complications $[1,2,14,19,20]$. Some other clinical trials have focused on determining the optimal longevity of the use of dexamethasone in treating bacterial meningitis [21-23].

Recently, studies covering high income countries have reported that the use of dexamethasone reduces hearing loss and neurological sequelae, increases recurrent fever and has no effect on the mortality rate from bacterial meningitis [24, 25]. It has to be emphasized that the abovementioned clinical and animal studies use protein and CSF glucose concentrations as markers to determine the degree of BBB damage. Furthermore, it is reported that the best parameters to determine the degree of BBB damage are concentrations of albumins and the albumin coefficient [26, 27]. Clinical studies conducted in patients suffering from viral encephalitis $[8,9]$ and a study conducted in patients with bacterial meningitis [10] found that high albumin CSF concentrations and albumin coefficient correspond with prolonged hospitalization and can predict outcome of the disease.

Considering these facts, the aim of the study was to investigate and to compare the influence of albumin concentration and the albumin coefficient, as parameters of BBB damage, on the outcomes of patients with purulent meningitis, as well as the influence of dexamethasone on BBB recovery.

\section{Material and methods}

The study was carried out by examining the hospitalized patients in Kosovo (a low income country), in a third level hospital - the Clinic of Infective Diseases in Prishtina. The study was approved by the ethical committee of the Faculty of Medicine, University of Prishtina, Kosovo. From a total of 329 enrolled patients, 187 (56.83\%) patients had a confirmed bacterial etiology, whereas 142 (43.16\%) patients were treated for probable purulent meningitis, based on World Health Organization (WHO) criteria: clinical signs and symptoms of meningitis, changes in CSF (high proteins and low glucose), and lack of an identifiable bacterial pathogen. The patients who did not fulfill these criteria were excluded from the study. In each patient included in the study, the following procedures were performed on admission: lumbar puncture, CSF analysis (cell count with differential, glucose, and proteins), Gram staining, CSF and blood bacterial culture and repeated lumbar puncture (LPS) after $48 \mathrm{~h}$.

The patients were divided into the three groups; the first group was treated without dexamethasone, the second group was treated with dexamethasone for up to $72 \mathrm{~h}$, and the third group was treated with dexamethasone for longer than $72 \mathrm{~h}$ (Figure 1). The treatment was followed by laboratory analysis and evaluation by an oph-

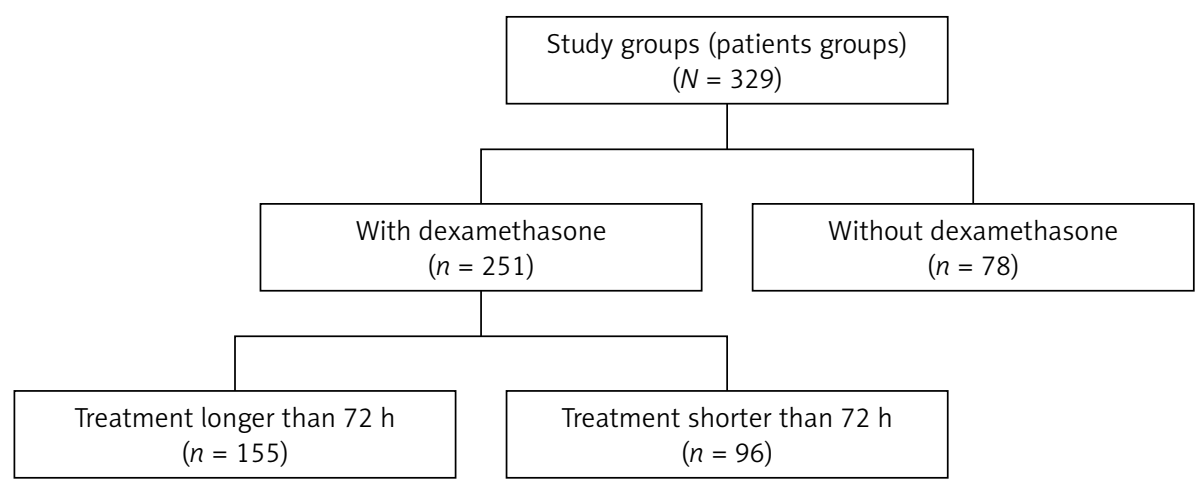

Figure 1. Flow chart showing study design 
thalmologist and an ENT specialist. The diagnosis of neurologic complications (hydrocephalus, epilepsy, blindness, deafness, cerebral abscesses, subdural empyema, cranial and peripheral nerve palsy, ventriculitis and psychomotor retardation) was performed by neurologic examination, neuroimaging and electroencephalography. Indications for performing neuroimaging (computed tomography $(\mathrm{CT})$ or magnetic resonance imaging $(\mathrm{MRI})$ ) of the head during meningitis were: prolonged fever, focal neurological deficit, convulsions, worsening consciousness level, prolonged cytobiochemical changes in CSF, or worsening of clinical presentation. The patients were clinically examined at least twice daily. Additionally, the patients were followed as outpatients for the next 4 years. The initial antibiotic therapy was determined based on the clinical presentation, altered mental state, seizures, neurologic deficit, the possible pathogen for each age group, the local antibiotic resistance patterns, previous treatment with antibiotics, the presence of a primary infectious focus, petechial or skin rash, and underlying diseases.

Subsequently, the antibiotic treatment was adopted in compliance with the microbiological and antibiogram data. Dexamethasone, as an adjuvant, was used from the beginning of the treatment $(0.15 \mathrm{mg} / \mathrm{kg}$ every $6 \mathrm{~h})$ for $72 \mathrm{~h}$, or longer, in accordance with the severity of disease.

The effect of treatment was evaluated, clinically as well as by analyzing the dynamics in the val- ues of proteins (determined by the turbidimetric method), glucose (determined by the colorimetric GOD-PAP method), albumins (determined by the BCG (bromocresol green method), and by determining the BBB coefficient of damage $[26,27]$.

The albumin coefficient is calculated based on the formula: $C=$ (Albumin concentration in CSF/ Albumin concentration in serum) $\times 1000$.

The reference value of the albumin coefficient was $1.8-7.4 \times 10^{-3}$. An albumin coefficient value less than 9 is considered normal, a value of 10-14 indicates mild $B B B$ dysfunction, 15-30 severe BBB dysfunction, 31-100 very severe BBB dysfunction, and if it is greater than 100 , it indicates complete collapse of BBB functions $[25,26]$.

\section{Statistical analysis}

ANOVA tests for multiple comparisons, as well as the RR, were used for statistical data processing.

\section{Results}

A total number of 329 patients were assigned to the study group, which included 246 (75.1\%) infants and children and 83 (24.9\%) adults (adults defined as persons of 16 years of age or older).

Table I presents summarized data of the patients involved in this study.

Among 329 patients who fulfilled criteria for purulent meningitis, the etiology was confirmed in 187 (56.83\%). The main causative agents con-

Table I. Summary of patients' characteristics and disease outcome

\begin{tabular}{|c|c|c|c|c|}
\hline \multirow[t]{2}{*}{ Parameter } & \multicolumn{2}{|c|}{ Dexamethasone } & \multirow[t]{2}{*}{ Placebo } & \multirow[t]{2}{*}{ Total } \\
\hline & Shorter than $72 \mathrm{~h}$ & Longer than $72 \mathrm{~h}$ & & \\
\hline Number of patients & 155 & 96 & 78 & 329 \\
\hline Age [years] & $7.0 \pm 12.9$ & $7.53 \pm 12.79$ & $17.46 \pm 15.26$ & $9.63 \pm 14.17$ \\
\hline Gender ratio F/M & $1.62 / 1$ & $1.58 / 1$ & $1.7 / 1$ & $1.66 / 1$ \\
\hline \multicolumn{5}{|c|}{ Duration of symptoms before admission [h]: } \\
\hline Mean & 72 & 72 & 24 & 48 \\
\hline Range & $1-216$ & $1-216$ & $1-120$ & $1-216$ \\
\hline Complications & $62(25.5 \%)$ & $2(20.83)$ & $2(2.56 \%)$ & $66(20.0 \%)$ \\
\hline Mortality rate & $15(5.98 \%)$ & 0 & $23(29.5 \%)$ & $38(11.55 \%)$ \\
\hline Etiology confirmed: & 88 & 32 & 67 & $187(56.83 \%)$ \\
\hline N. meningitides & 52 & 5 & 24 & $81(43.3 \%)$ \\
\hline Pneumococcus & 10 & 15 & 18 & $43(23.0 \%)$ \\
\hline H. influenzae & 15 & 3 & 12 & $30(16.0 \%)$ \\
\hline Staph. aureus & 6 & 4 & 3 & $13(6.95 \%)$ \\
\hline Gram negative bacilli & 5 & 5 & 10 & $20(10.69 \%)$ \\
\hline Etiology not confirmed & 67 & 64 & 11 & $142(43.17 \%)$ \\
\hline
\end{tabular}


firmed were $N$. meningitis, S. pneumoniae and H. influenzae, responsible for $116(82.3 \%)$ patients of etiologically confirmed patients with purulent meningitis. From 329 patients, 38 died (lethality $11.55 \%)$, and $66(20.0 \%)$ patients developed different CNS complications (among them 11 patients developed more than one complication).

The most frequent CNS complications were subdural empyema in 27 (8.2\%) patients, hydrocephalus in 15 (4.5\%) patients, cerebral abscess in $9(2.7 \%)$ patients and epilepsy in 8 (2.4\%) patients.

High CSF pleocytosis was evidenced in all three groups of patients with purulent meningitis, at the beginning of the diseases (Table II). The duration of polymorphonuclear pleocytosis in patients with complications was significantly longer compared to patients without complications $(p<0.001)$. Persistence of polymorphonuclear pleocytosis longer than 10 days was evidenced in patients with severe forms of meningitis, as well as in those who developed complications.

Low CSF glucose was evidenced in all three groups of patients in the beginning, whereas duration of CSF low glucose in patients surviving disease without complications was significantly shorter $(p<0.001)$ compared to patients who developed complications. Similar to the persistence of pleocytosis, persistence of hypoglycorrachia in the second week of treatment suggests developing complications.

Higher values of CSF proteins were evidenced in patients with a lethal outcome, and in those who developed complications. A significant difference $(p<0.001)$ was found in the values of proteins, when comparing the patients with and without complications at the beginning of the disease. The duration of a high level of CSF proteins in the patients without complications was significantly shorter $(p<0.001)$ compared to patients who developed complications.

The highest values of CSF albumins are found in patients with a lethal outcome $(\bar{X}=3.475 \pm 2.96$ $\mathrm{g} / \mathrm{l})$ and were significantly higher $(p<0.001)$ compared to patients without complications $(\bar{X}=1.46$ $\pm 0.78 \mathrm{~g} / \mathrm{l})$. In the patients without complications the duration of pathological concentrations of albumins was significantly $(p<0.001)$ shorter compared to patients who have developed complications. Similar findings were encountered when we analyzed data in different albumins (transudate and exudate, data not presented).

The majority of patients with purulent meningitis presented very severe BBB damage (Figure 2). Among the patients with complications, 64.3\% had very severe BBB damage, whereas $4.8 \%$ presented a collapse of BBB functions. Among the patients with a lethal outcome, the percentage of patients with very severe BBB damage was $58.3 \%$ whereas $41.7 \%$ presented a collapse of BBB functions.

Mean values of albumin coefficient was the lowest in patients surviving disease without complications, $\bar{X}=30.75 \pm 36.61$, whereas it was much higher in complicated patients, $\bar{X}=46.5 \pm 27.23$, as well as in patients with a lethal outcome, $\bar{X}=96.25 \pm 78.9$ (Table III).

The mean duration of the pathological value of the albumin coefficient in all 329 patients was

Table II. Summary of CSF biochemical changes in patients with purulent meningitis and the disease outcome

\begin{tabular}{|c|c|c|c|c|c|c|c|c|c|c|}
\hline \multirow{2}{*}{\multicolumn{2}{|c|}{ Parameter }} & \multicolumn{3}{|c|}{$\begin{array}{l}\text { Without dexamethasone } \\
\qquad(n=78)\end{array}$} & \multicolumn{3}{|c|}{$\begin{array}{c}\text { With dexamethasone, } \\
\text { shorter than } 72 \mathrm{~h}(n=155)\end{array}$} & \multicolumn{3}{|c|}{$\begin{array}{l}\text { With dexamethasone, } \\
\text { longer than } 72 \mathrm{~h}(n=96)\end{array}$} \\
\hline & & Cured & $\begin{array}{l}\text { Compli- } \\
\text { cated }\end{array}$ & Lethal & Cured & $\begin{array}{l}\text { Compli- } \\
\text { cated }\end{array}$ & Lethal & Cured & $\begin{array}{l}\text { Compli- } \\
\text { cated }\end{array}$ & Lethal \\
\hline \multicolumn{2}{|c|}{ Number of patients } & 53 & 2 & 23 & 78 & 62 & 15 & 94 & 2 & 0 \\
\hline \multirow{2}{*}{$\begin{array}{l}\text { CSF pleocytosis } \\
\text { mean value [/ } \\
\left.\mathrm{mm}^{3}\right]\end{array}$} & Day 0 & 7755 & 7734 & 7931 & 8030 & 6643.3 & 10000 & 8072 & 10000 & - \\
\hline & $\begin{array}{l}\text { Duration } \\
\text { [days] }\end{array}$ & 7.735 & 27 & - & 6.38 & 14.5 & - & 9.37 & 14 & - \\
\hline \multirow{2}{*}{$\begin{array}{l}\text { CSF glucose } \\
\text { mean value } \\
{[\mathrm{mmol} / \mathrm{l}]}\end{array}$} & Day 0 & 1.87 & 1.500 & 1.205 & 1.765 & 1.508 & 0.705 & 1.75 & 0.900 & \\
\hline & $\begin{array}{l}\text { Duration } \\
\text { [days] }\end{array}$ & 6.64 & 24.00 & - & 8.63 & 24.24 & - & 7.37 & 18 & - \\
\hline \multirow{2}{*}{$\begin{array}{l}\text { CSF proteins } \\
\text { mean value } \\
{[\mathrm{g} / \mathrm{l}]}\end{array}$} & Day 0 & 1.75 & 1.9 & 4.17 & 1.69 & 2.39 & 2.80 & 1.88 & 2.35 & - \\
\hline & $\begin{array}{l}\text { Duration } \\
\text { [days] }\end{array}$ & 10.3 & 31.0 & - & 12.74 & 30.5 & - & 15.98 & 25.0 & - \\
\hline \multirow{2}{*}{$\begin{array}{l}\text { CSF albumins } \\
\text { mean value } \\
{[g / l]}\end{array}$} & Day 0 & 1.65 & 1.63 & 3.47 & 1.52 & 2.22 & 2.96 & 1.35 & 1.83 & \\
\hline & $\begin{array}{l}\text { Duration } \\
\text { [days] }\end{array}$ & 11.95 & 13 & - & 11.54 & 26 & - & 15.42 & 32.16 & \\
\hline \multirow{2}{*}{$\begin{array}{l}\text { Albumin } \\
\text { coefficient }\end{array}$} & Day 0 & 44.9 & 37.0 & 96.25 & 40.49 & 53.5 & 78.88 & 34.14 & 46.64 & \\
\hline & $\begin{array}{l}\text { Duration } \\
\text { [days] }\end{array}$ & 11.75 & 20 & - & 12.74 & 33.84 & - & 14.7 & 26.0 & \\
\hline
\end{tabular}


A

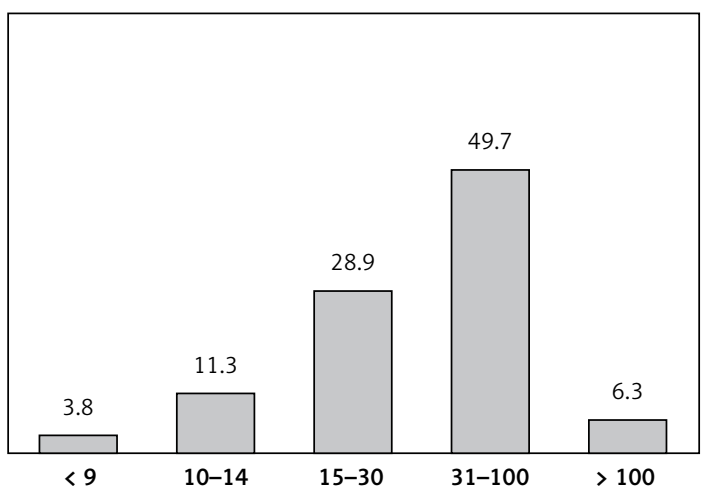

C

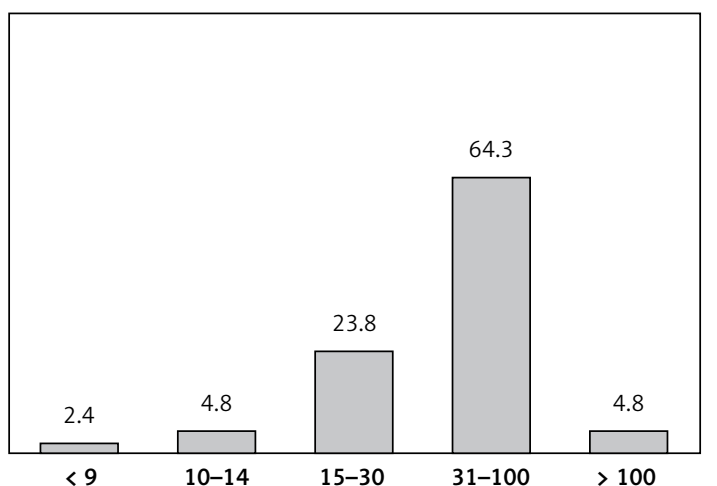

B

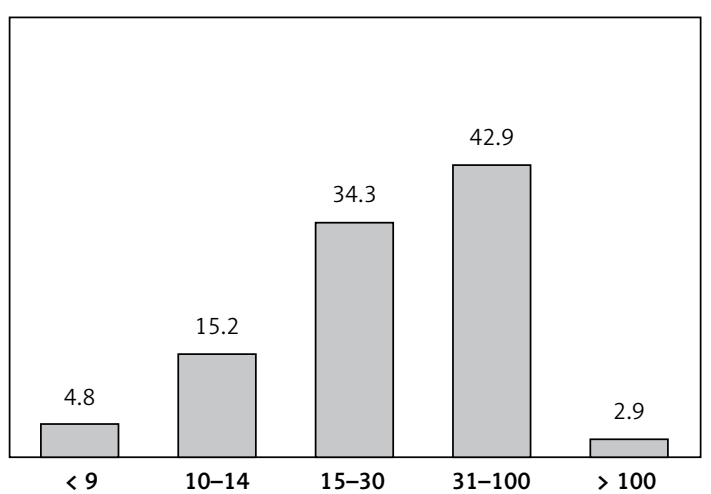

D

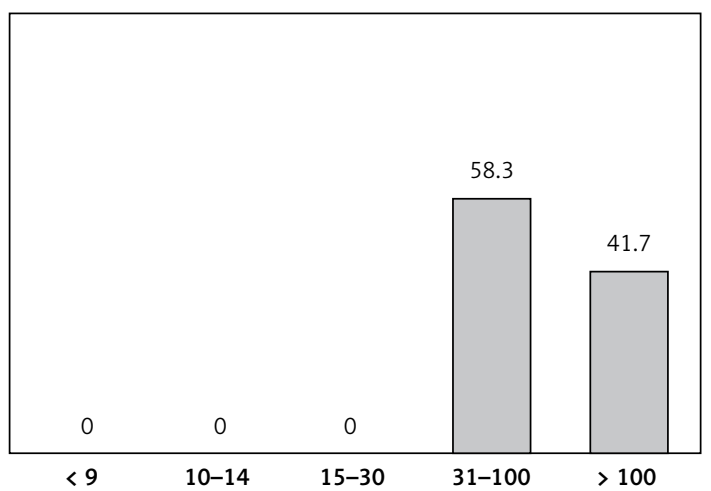

Figure 2. Percentage of patients with different severity levels of BBB damage on the day of admission: $\mathrm{A}-\mathrm{all}$ patients, $N=329$, B - patients without complications, $n=225, \mathrm{C}-$ patients with complications, $n=66, \mathrm{D}-$ patients with lethal outcome, $n=38$

$\bar{X}=18.98$ days. In the patients without complications the duration of the pathological value of the albumin coefficient was $\bar{X}=13.47$ days, which is significantly shorter $(p<0.001)$ compared to patients who developed complications $(\bar{X}=32.76$ days).

Analyzing BBB damage parameters in predicting the expected outcome of the patients with purulent meningitis, it was found that the most sensitive parameter for poor outcome was the albumin coefficient and duration of its pathological values. Patients with a mean value of albumin coefficient $\bar{X}=46.5 \pm 27.23 \mathrm{~g} / \mathrm{l}$ are at higher risk of developing complications $(\mathrm{RR}=2.63$; lower limit $=2.13$; upper limit $=3.26 ; p<0.0001$ ) or having a lethal outcome $(R R=5.20$; lower limit = 3.88; upper limit $=6.98 ; p<0.0001$ ), compared to the mean values of the albumin coefficient found in patients who survived the disease without complications. Furthermore, patients with longer duration of pathological mean values of the albumin coefficient are at higher risk of developing complications $(R R=3.11$; lower limit $=2.51$; upper limit $=3.83 ; p<0.0001)$. In addition, the multivariate logistic regression analysis for other parameters, such as pleocytosis, hypoglycorrachia, and hyperproteinorachia, were shown to be less predictive for the outcome of patients with purulent meningitis (Table III).

\section{Discussion}

Despite the progress in medicine, bacterial meningitis still causes severe morbidity and high lethality in all age groups, in both developed and developing countries $[1,2,11,12,14,17,24,28]$.

Therefore, finding reliable predictors of this serious disease has been the aim of many studies that have used various clinical and laboratory parameters [28-31]. It is worth underlining that the addition of laboratory tests to a score has only marginally improved the accuracy of the results [29].

Furthermore, even though the CSF cultures become sterile for 24-48 h with antibiotic treatment, the high rate of mortality and neurological complications demand additional research work [5, 14, 23, 32]. Animal research showed that bacterial lysis results in increased subarachnoid inflammation, increasing the risk of a worse outcome of the disease $[3,17]$, as a result of releasing inflammatory interleukins through destroying bacteria [4-6, 30].

Several serum and CSF parameters are analyzed in predicting the outcome of the disease. 
Soluble urokinase receptor values in CSF [33], PCT [34], CRP [35], matrix metalloproteinase-9, tissue inhibitor of metalloproteinase-1 [36], and CD64 [37], correspond to the severity and outcome of purulent meningitis.

It is a well-known fact that concentrations of albumins and the albumin coefficient are gold standard measures of BBB function [26, 27, 3840]. However, the data for purulent meningitis and predictive concentrations of albumins and the albumin coefficient in disease outcome are limited $[32,40]$.

Moreover, animal and human investigations have found that the use of dexamethasone improves the BBB damage and reduces neurological complications and CSF inflammation $[1,2,14,17$, $19,22,25,30]$. According to our data, the BBB damage is intensive during purulent meningitis and it constitutes a sensitive parameter in the outcome of the disease $[6,14,21,25,29,31]$.

Our data indicate that the patients who developed complications have much longer persistence of CSF pleocytosis with polymorphonuclear (PMN) predominance compared to the survivors without complications. Additionally, the CSF glucose concentrations at the beginning of the disease were low and corresponded with the outcome of the disease, which is reported by other authors too [14, 28, 31].

During the first $72 \mathrm{~h}$, in patients who have been treated with dexamethasone, a drop in protein concentration was observed (which was not the case with the patients treated without dexamethasone). Later on in the course of the disease, the use of dexamethasone had a minor influence on protein concentrations in patients surviving the disease with or without complications. A high value of proteins in CSF at the beginning of the disease was found to be an important outcome predictor in patients with purulent meningitis, due to the fact that higher values have been evidenced in patients with a lethal outcome, as well as those who developed complications [31].

Analyzing BBB damage parameters in predicting the outcome of patients with purulent meningitis, it was found that the most sensitive parameter for poor outcome of the disease was the albumin coefficient and duration of its pathological values. The albumin coefficient in our patients with purulent meningitis presents severe and very severe BBB damage that directly corresponds with the outcome of the disease. The severity of this disease within all patients included in the study was documented as follows: $28.9 \%$ of the patients had severe BBB damage, $49.7 \%$ very severe BBB damage, and $6.3 \%$ had collapse of BBB functions. Very severe damage and collapse of BBB functions were more often found in patients with a poor outcome.

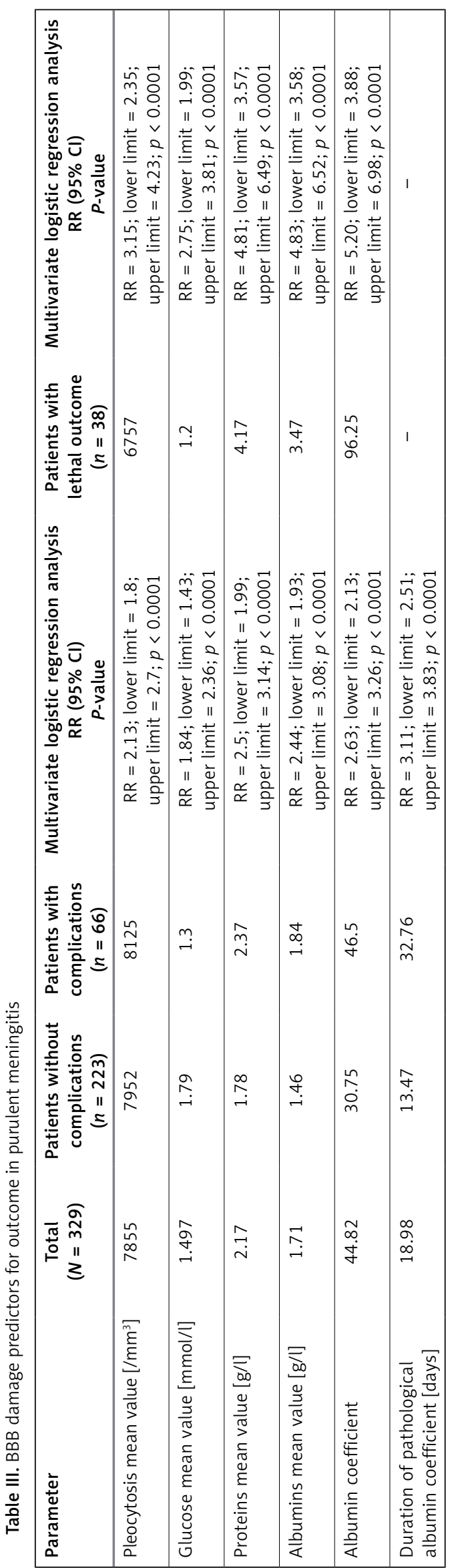


The RR values obtained from our data show that the duration of a pathological albumin coefficient and mean value of albumins were the most sensitive parameters in predicting the disease outcome. According to RR values, other parameters such as pleocytosis, proteins and low glucose show less predictive value for outcome according to RR values.

In conclusion, according to our data, the BBB damage in patients with purulent meningitis is very severe and corresponds with disease outcome. The best predictors of poor outcome are the albumin coefficient, pathological values of albumins, and concentration of proteins. However, further larger studies in this field need to be carried out on BBB damage in predicting the outcome of purulent meningitis.

\section{Conflict of interest}

The authors declare no conflict of interest.

\section{References}

1. Baunbæk-Knudsen G, Sølling M, Farre A, Benfield T, Brandt CT. Improved outcome of bacterial meningitis associated with use of corticosteroid treatment. Infect Dis 2016; 48: 281-6.

2. van de Beek D. Corticosteroids for acute adult bacterial meningitis. Med Mal Infect 2009; 39: 531-8.

3. Tauber MG, Khayam-Bashi H, Sande MA. Effects of ampicillin and corticosteroids on brain water content, cerebrospinal fluid pressure, and cerebrospinal fluid lactate levels in experimental pneumococcal meningitis. J Infect Dis 1985; 151: 528-34.

4. Padridge WM. Drug delivery to the brain. J Cereb Blood Flow Metab 1997; 17: 713-31.

5. Kieseier BC, Paul R, Koedel U, et al. Differential expression of matrix metalloproteinases in bacterial meningitis. Brain 1999; 122: 1579-87.

6. Koedel U, Bernatowicz A, Paul R, Frei K, Fontana A, Pfister HW. Experimental pneumococcal meningitis: cerebrovascular alterations, brain edema, and meningeal inflammation are linked to the production of nitric oxide. Ann Neurol 1995; 37: 313-23.

7. Lutsar I, Friedland IR, Jafri HS, et al. Factors influencing the anti-inflammatory effect of dexamethasone therapy in experimental pneumococcal meningitis. J Antimicrob Chemother 2003; 52: 651-5.

8. Hoyer C, Eisele P, Ebert AD, et al. Blood-CSF-barrier dysfunction is a marker for encephalitic involvement in patients with aseptic meningitis/meningoencephalitis. J Clin Virol 2016; 84: 82-6.

9. Alonso A, Eisele P, Ebert AD, et al. Leptomeningeal contrast enhancement and blood-CSF barrier dysfunction in aseptic meningitis. Neurol Neuroimmunol 2015; 2: e164.

10. Dzupova O, Rozsypal H, Prochazka B, Benes J. Acute bacterial meningitis in adults: predictors of outcome. Scand J Infect Dis 2009; 41: 348-54.

11. Arguedas AG. Marks IM. Recent advances in the treatment of meningitis, including steroids. Curr Opin Infections Dis 1991; 4: 491-9.

12. Bedford H, de Louvois J, Halket S, Peckham C, Hurley R, Harvey D. Meningitis in infancy in England and Wales: follow up at age 5 years. BMJ 2001; 323: 533-6.
13. Cabellos C, Martínez-Lacasa J, Tubau F, et al. Evaluation of combined ceftriaxone and dexamethasone therapy in experimental cephalosporin-resistant pneumococcal meningitis. J Antimicrob Chemother 2000; 45: 315-20.

14. Ciana G, Parmar N, Antonio C, Pivetta S, Tamburlini G, Cuttini $M$. Effectiveness of adjunctive treatment with steroids in reducing short-term mortality in a high-risk population of children with bacterial meningitis. J Trop Pediatr 1995; 41: 164-8.

15. Daoud AS, Batieha A, Al-Sheyyab M, Abuekteish F, Obeidat A, Mahafza T. Lack of effectiveness of dexamethasone in neonatal bacterial meningitis. Eur J Pediatr 1999; 158: 230-3.

16. Fortnum $\mathrm{H}$, Davis A. Hearing impairment in children after bacterial meningitis: incidence and resource implications. Br J Audiol 1993; 27: 43-52.

17. de Gans J, van de Beek D. European dexamethasone in Adulthood Bacterial Meningitis Study Investigators. Dexamethasone in adults with bacterial meningitis. N Engl J Med 2002; 14: 1549-56.

18. Giasuddin AS, Shembesh NM, el-Bargathy SM, Kashbur IM, Rao BN. Levels of serum immunoglobulin G, CSF IgG index in acute meningitis. Br J Biomed Sci 1998; 55: 253-7.

19. Rappaport JM, Bhatt SM, Burkard RF, Merchant SN, Nadol JB Jr. Prevention of hearing loss in experimental pneumococcal meningitis by administration of dexamethasone and ketorolac. J Infect Dis 1999; 179: 264-8.

20. Tolaj I, Dreshaj S, Qehaja E, Tolaj J, Doda-Ejupi T, Mehmeti $M$. Dexamethasone as adjuvant therapy in the treatment of invasive meningococcal diseases. Med Arch 2010; 64: 228-30.

21. Greenwood BM. Corticosteroids for acute bacterial meningitis. N Engl J Med 2007; 13: 2507-9.

22. Quagliarello VJ, Scheld WM. Treatment of bacterial meningitis. N Engl J Med 1997; 336: 708-16.

23. Syrogiannopoulos GA, Lourida AN, Theodoridou MC, et al. Dexamethasone therapy for bacterial meningitis in children: 2- versus 4-day regimen. J Infect Dis 1994; 169: 853-8.

24. Brouwer MC, McIntyre P, Prasad K, van de Beek D. Corticosteroids for acute bacterial meningitis. Cochrane Database Syst Rev 2015; 12: CD004405.

25. Kobayashi Y, Sunakawa K, Fujita K, et al. Influence of dexamethasone on the clinical course of bacterial meningitis in children. Especially on secondary fever. Experiences in 27 institutions. Kansenshogaku Zasshi 1999; 73: 664-74.

26. Kaplan L, Pesce A. Clinical Chemistry. Theory, Analysis, Correlation. $5^{\text {th }}$ ed. Elsevier Inc; MI: St. Luis 2010; 904-28.

27. Blyth BJ, Farhavar A, Gee C, et al. Validation of serum markers for blood-brain barrier disruption in traumatic brain injury. J Neurotrauma 2009; 26: 1497-507.

28. Bijlsma MW, Brouwer MC, Kasanmoentalib ES, et al. Community-acquired bacterial meningitis in adults in the Netherlands, 2006-14: a prospective cohort study. Lancet Infect Dis 2016; 16: 339-47.

29. Pelkonen T, Roine I, Monteiro L, et al. Prognostic accuracy of five simple scales in childhood bacterial meningitis. Scand J Infect Dis 2012; 44: 557-65.

30. Perdomo-Celis F, Torres MA, Ostos $\mathrm{H}$, et al. Patterns of local and systemic cytokines in bacterial meningitis and its relation with severity and long-term sequelae. Biomark Insights 2015; 20: 125-31.

31. Tan J, Kan J, Qiu G, et al. Clinical prognosis in neonatal bacterial meningitis: the role of cerebrospinal fluid protein. PLoS One 2015; 28: e0141620. 
32. Tzanakaki G, Paparoupa M, Kyprianou M, Barbouni A, Eugen-Olsen J, Kourea-Kremastinou J. Elevated soluble urokinase receptor values in CSF, age and bacterial meningitis infection are independent and additive risk factors of fatal outcome. Eur J Clin Microbiol Infect Dis 2012; 31: 1157-62.

33. Hu R, Gong Y, Wang Y. Relationship of serum procalcitonin levels to severity and prognosis in pediatric bacterial meningitis. Clin Pediatr (Phila) 2015; 54: 1141-4.

34. Olaciregui I, Hernández U, Muñoz JA, Emparanza JI, Landa JJ. Markers that predict serious bacterial infection in infants under 3 months of age presenting with fever of unknown origin. Arch Dis Child 2009; 94: 501-5.

35. Roine I, Pelkonen T, Bernardino L, et al. Predictive value of cerebrospinal fluid matrix metalloproteinase- 9 and tissue inhibitor of metalloproteinase-1 concentrations in childhood bacterial meningitis. Pediatr Infect Dis J 2014; 33: 675-9.

36. Liu C, Zhao D. Correlation between CD64 and PCT levels in cerebrospinal fluid and degree of hearing impairment sequelae in neonates with purulent meningitis. Exp Ther Med 2017; 14: 5997-6001.

37. Jebamalar AA, Prabhat, Balakrishnapillai AK, Parmeswaran N, Dhiman P, Rajendiran S. Cerebrospinal fluid ferritin and albumin index: potential candidates for scoring system to differentiate between bacterial and viral meningitis in children. Biomarkers 2016; 21: 424-8.

38. Durgawale P, Kanase S, Shukla PS, Sontakke S. A sensitive and economical modified method for estimation of cerebrospinal fluid proteins. Indian J Clin Biochem 2005; 20: 174-7.

39. Croci D, Nespolo A, Bosoni MA, Tarenghi G. A simple immunoturbidimetric method for IgG and albumin quantitation in cerebrospinal fluid and serum. J Clin Chem Clin Biochem 1989; 27: 863-8.

40. Valkov T, Hristova J, Tcherveniakova T, Svinarov D. Bloodbrain barrier and intrathecal immune response in patients with neuroinfections. Infez Med 2017; 25: 320-5. 